\section{'TAM Mild Jalapeño II': A New, Multiple-virus-resistant, Mild Jalapeño Pepper}

\author{
Kevin M. Crosby ${ }^{1}$ and Benigno Villalon ${ }^{2}$ \\ Texas Agricultural Experiment Station, 2415 E. Highway 83, Weslaco, \\ TX 78596
}

\section{Additional index words. Capsicum annuum, potyviruses, resistance, germplasm, open- pollinated}

The Texas Agricultural Experiment Station (TAES) at Weslaco announces the release of 'TAM Mild Jalapeño II', a multiple-virusresistant, low-pungency pepper (Capsicum annuит L.). The project to breed virus-resistant peppers at the TAES began in 1971. Several cultivars of virus-resistant jalapeños have been released over the last 20 years (Villalon, 1983; Villalon et al., 1992, 1994). The production of hot and sweet peppers in Texas has fluctuated from 1200 to 7000 ha over the last 30 years. Currently, close to 1700 ha are cultivated statewide. One of the most persistent problems on peppers in south Texas has been virus infection. The two most serious virus pathogens are tobacco etch virus (TEV) and pepper mottle virus (PepMov), both transmitted by aphidsprimarily the cotton aphid (Aphis gossypii Glover) and the green peach aphid (Myzus persicae Sulzer). Traditionally, all common jalapeño cultivars grown in south Texas have been susceptible to local strains of TEV and PepMov. Yield reductions from infected plants may be as high as $45 \%$, particularly when fruit is intended for the fresh market (Greenleaf, 1986). The best solution to the problem is the development of resistant cultivars with highquality fruit. Multiple sources of single resistance genes against these potyviruses have been documented in various germplasm lines (Cook, 1960; Greenleaf, 1956; Kyle and Palloix, 1997; Zitter and Cook, 1973).

\section{Origin}

'TAM Mild Jalapeño II' (TMJ II) originated from an $F_{12}$ selection out of the cross of 'Ferry Morse Jumbo Jalapeño' and sweet jalapeño 76053, a line with resistance to Texas isolates of TEV, PVY, PepMov, and TMV (Fig. 1).

\footnotetext{
Received for publication 30 Oct. 2001. Research conducted at the Texas Agricultural Experiment Station, Weslaco, Texas. Use of trade names does not imply endorsement of the products named nor criticism of similar ones not named. The authors thank Rick Hernandez, Cory Dombrowski, Kay Harding, and Alfredo Rodriguez for their valuable help in conducting greenhouse and field experiments. Thanks also to Dr. Richard Christie and Dr. John Kao for providing several different strains of TEV and Dr. Brad Reddick for providing a strain of PepMov.

${ }^{1}$ Assistant Professor, corresponding author: k-crosby@tamu.edu.

${ }^{2}$ Professor Emeritus.
}

This pedigree included three sources of potyvirus resistance, 'Avelar', 'PI 264281', and 'AC 2207' (Cook, 1960; Greenleaf, 1986; Zitter and Cook, 1973), as well as several jalapeñolines. Field selections were conducted for more than 12 generations. Progeny of the initial $\mathrm{F}_{3}$ single-plant selection were placed in isolation blocks for two consecutive seasons, bulking superior plants. This was followed by another single-plant selection. Selfed progeny of this plant were then grown in isolation blocks where superior plant selections were bulked to carry on the inbreeding. At each generation, seedlings were mechanically inoculated with Texas isolates of TEV and PepMov, prior to transplanting to the field, to verify resistance (Villalon, 1981). Susceptible control cultivars were included to ensure viral pathogenicity. The final selection was at the $\mathrm{F}_{12}$ generation and possessed uniform plant and fruit traits.

\section{Description}

'TAM Mild Jalapeño II' is adapted to the high temperatures and virus disease pressures of south Texas. The concentrated set of large,
Fig. 1. Pedigree of 'TAM Mild Jalapeño II'. different.

${ }^{y}$ A high-yielding sweet jalapeño breeding line. crack-free fruit on compact plants makes it ideally suited to once-over harvests and highdensity plantings. Comparisons for field performance, yield, fruit quality, and virus resistance were conducted at the TAES center at Weslaco during the period from 1996 to 2001. In addition, yield plots were established in a commercial field in Edinburg, Texas, during the Fall 2000 season. All plants were grown on a silty, clay loam soil (Weslaco) or sandy soil (Edinburg), under commercial practices: transplants, drip irrigation, and chemical pest control. Plants of both 'TMJ II' and 'Mitla', inoculated with TEV, PVY, and PepMov, were transplanted to $10-\mathrm{L}$ pots in the greenhouse and into field plots to observe effects on plant growth and fruit quality.

In the fall season, 'TMJ II' had significantly larger fruit and thicker flesh than 'Mitla', and similar yield per plant. In the spring season, fruit size and flesh thickness were significantly greater than 'Grande', but yield was significantly lower at $350 \mathrm{~g} / \mathrm{plant}$ compared to 372 g/plant (Table 1, Fig. 2). In both seasons, 'TMJ II' matured 5 d before 'Mitla,' at Weslaco. In the Fall 2000 season, yields and fruit quality were compared among 'TMJ II' and the commercial cultivars Mitla, Grande, and Tula, from a trial on sandy soils in Edinburg (Table 2). Yield of 'TMJ II' (435 g/plant) was not significantly different than the popular cultivar Grande (444 g/plant), but was significantly less than 'Mitla' (502 g/plant). However, the percentages of cull fruit for both 'TMJ II' (12\%) and 'Grande' (13\%) were significantly lower than the $19 \%$ level for 'Mitla'. In addition, 'TMJ II' fruit produced very little anthocyanin compared to fruit of 'Grande' and 'Mitla'. This purple-black pigment is undesirable for fresh-market peppers and reduces the value of the crop. Total capsaicin concentrations of mature fruits from 'TMJ II' plants grown in Uvalde and College Station,

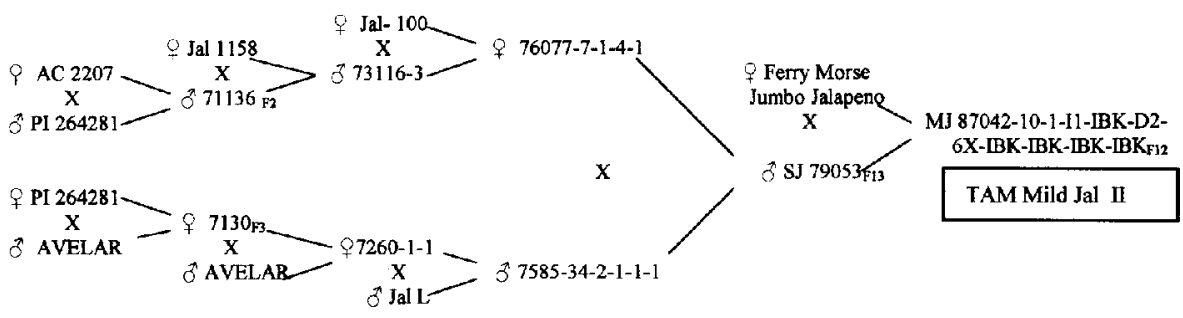

Table 1. Performance of 'TAM Mild Jalapeño II' and comparisons at Weslaco, Texas.

\begin{tabular}{lcccc}
\hline \hline Cultivar & $\begin{array}{c}\text { Fruit length } \\
(\mathrm{cm})\end{array}$ & $\begin{array}{c}\text { Flesh thickness } \\
(\mathrm{mm})\end{array}$ & $\begin{array}{c}\text { Weight/fruit } \\
(\mathrm{g})\end{array}$ & $\begin{array}{c}\text { Yield per plant } \\
(\mathrm{g})\end{array}$ \\
\hline & & Fall 1999 & & \\
TAM MJ II & $7.2 \mathrm{a}^{\mathrm{z}}$ & $4.6 \mathrm{a}$ & $31 \mathrm{a}$ & $412 \mathrm{~b}$ \\
SJ 82 & $7.1 \mathrm{a}$ & $4.6 \mathrm{a}$ & $32 \mathrm{a}$ & $442 \mathrm{a}$ \\
Mitla & $7.3 \mathrm{a}$ & $4.1 \mathrm{~b}$ & $23 \mathrm{~b}$ & $430 \mathrm{ab}$ \\
TAM MJ I & $6.5 \mathrm{~b}$ & $4.1 \mathrm{~b}$ & $20 \mathrm{~b}$ & $308 \mathrm{c}$ \\
& & Spring 2000 & & \\
TAM MJ II & $8.1 \mathrm{a}$ & $4.5 \mathrm{ab}$ & $34 \mathrm{a}$ & $350 \mathrm{c}$ \\
SJ 82 & $7.0 \mathrm{~b}$ & $4.7 \mathrm{a}$ & $34 \mathrm{a}$ & $407 \mathrm{a}$ \\
Grande & $7.1 \mathrm{~b}$ & $4.5 \mathrm{ab}$ & $30 \mathrm{~b}$ & $372 \mathrm{~b}$ \\
TAM MJ I & $6.6 \mathrm{c}$ & $4.3 \mathrm{~b}$ & $24 \mathrm{c}$ & $294 \mathrm{~d}$ \\
\hline
\end{tabular}

${ }^{2}$ Mean separations within tests by LSD, $P \leq 0.05$. Means followed by the same letter are not significantly 


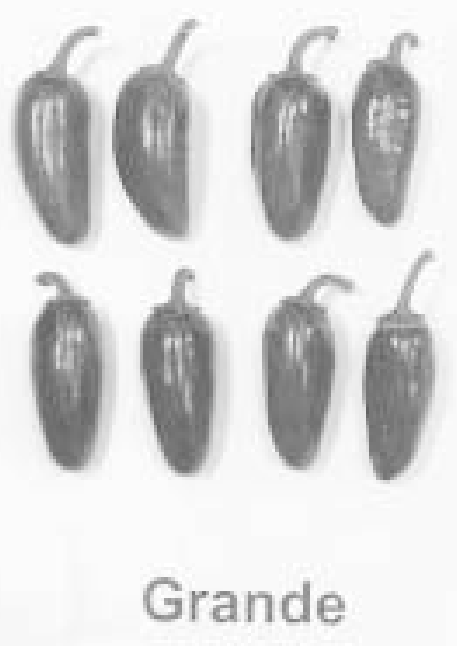

Fig. 2. Fruit of 'Grande' and 'TAM Mild Jalapeño II'.

Table 2. Performance of 'TAM Mild Jalapeño II' and comparisons at Edinburg, Texas, Fall 2000.

\begin{tabular}{lcccr}
\hline \hline Cultivar & $\begin{array}{c}\text { Fruit length } \\
(\mathrm{cm})\end{array}$ & $\begin{array}{c}\text { Weight/fruit } \\
(\mathrm{g})\end{array}$ & $\begin{array}{c}\text { Yield per plant } \\
(\mathrm{g})\end{array}$ & $\begin{array}{r}\text { Culls } \\
(\%)\end{array}$ \\
\hline TAM MJ II & $8.0 \mathrm{a}^{\mathrm{z}}$ & $33 \mathrm{ab}$ & $435 \mathrm{~b}$ & $12 \mathrm{~b}$ \\
Mitla & $7.0 \mathrm{c}$ & $24 \mathrm{c}$ & $502 \mathrm{a}$ & $19 \mathrm{a}$ \\
Grande & $7.5 \mathrm{~b}$ & $31 \mathrm{~b}$ & $444 \mathrm{~b}$ & $13 \mathrm{~b}$ \\
Tula & $7.5 \mathrm{~b}$ & $36 \mathrm{a}$ & $371 \mathrm{c}$ & $6 \mathrm{c}$ \\
TAM MJ I & $6.5 \mathrm{~d}$ & $21 \mathrm{c}$ & $315 \mathrm{~d}$ & $12 \mathrm{~b}$
\end{tabular}

${ }^{2}$ Mean separations by LSD, $P \leq 0.05$. Means followed by the same letter are not significantly different.

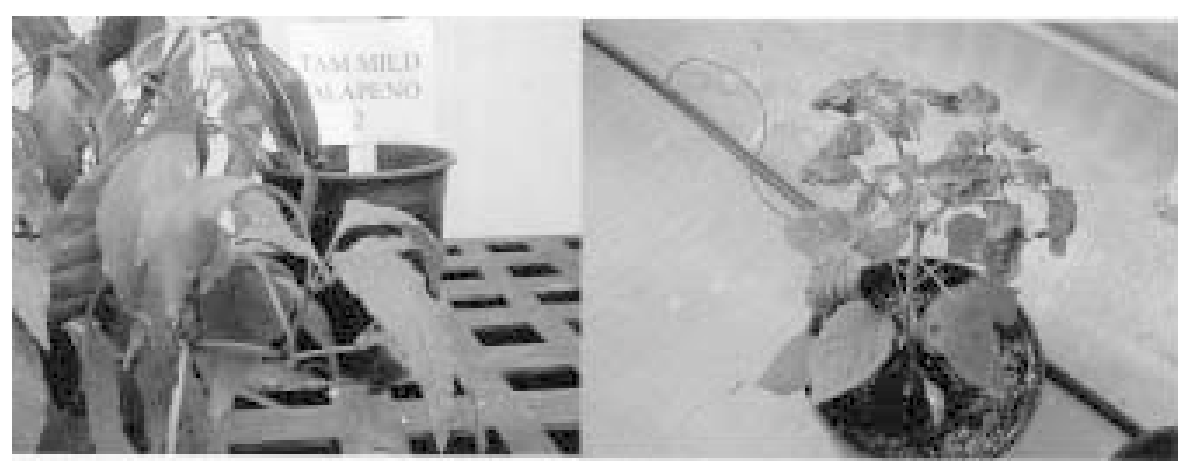

Fig. 3. Effects of TEV (H92-31) on resistant 'TAM Mild Jalapeño II' vs. susceptible 'Ancho'.

Texas, in Spring 2001, were measured by high-performance liquid chromatography (Hoffman et al., 1983). Fruits from a hot jalapeño cultivar, 'Grande', grown in College Station, were also analyzed for comparison. Total capsaicin, on a dry-weight basis, was converted to Scoville Heat Units (SHU) following the method of Collins et al. (1995). 'TMJ II' fruit from College Station had higher total capsaicin $\left(108 \mathrm{mg} \cdot \mathrm{kg}^{-1}, 1620 \mathrm{SHU}\right)$ than fruit from Uvalde (72 $\left.\mathrm{mg} \cdot \mathrm{kg}^{-1}, 1080 \mathrm{SHU}\right)$. By comparison, the hot jalapeño 'Grande' had a capsaicin concentration of $1332 \mathrm{mg} \cdot \mathrm{kg}^{-1}$ (19980 SHU).

In both greenhouse and field plots, TEVinoculated plants of 'Mitla' had small, misshapen fruit, and chlorotic leaves, while inoculated plants of 'TMJ II' had normal fruit and no chlorosis (Fig. 3). None of the plants appeared to be reduced in height. PepMovinoculated plants of 'Mitla' exhibited severe leaf distortion, plant stunting, and reduced yield of misshapen fruit. 'TMJ II' plants inoculated with PepMov exhibited mild chlorosis on older leaves but no distortion or misshapen fruit. No symptoms were observed on 'TMJ II' or 'Mitla' after inoculation with PVY. ELISA tests were conducted on leaf samples from inoculated plants of 'TMJ II' and 'Mitla' to determine the presence of TEV, PepMov, and PVY. Leaves from 'Mitla' tested positive for TEV and PepMov with absorbance readings of 1.70 and 2.21 , respectively, but negative for PVY (0.021). Leaves from 'TMJ II' tested negative for TEV (0.047) and PVY (0.019) and weakly positive for PepMov (0.49). Susceptible control bell pepper leaves tested positive for TEV (4.0) and PepMov (2.37).

The large, low-pungency fruit of 'TMJ II' will make it equally suited for fresh-market and processing uses. The multiple-virus resistance and adaptation to high temperatures will be valuable attributes in regions where these stresses exist.

\section{Availability}

Breeder's seed will be maintained by the Texas Agricultural Experiment Station at Weslaco. Application for plant variety protection is being filed for 'TMJ II'. This cultivar may be licensed through the Texas Agricultural Experiment Station, for commercial seed production.

\section{Literature Cited}

Collins, M.D., L.M. Wasmund, and P.W. Bosland. 1995. Improved method for quantifying capsaicinoids in Capsicum using high-performance liquid chromatography. HortScience 30:137-139.

Cook, A.A. 1960. Genetics of resistance in Capsicum annuит to two virus diseases. Phytopathology 50:364-367.

Greenleaf, W.H. 1956. Inheritance of resistance to tobacco etch virus in Capsicumfrutescens and in Capsicum annuum. Phytopathology 46:371-375.

Greenleaf, W.H. 1986. Pepper breeding, p. 67-134. In: M.J. Basset (ed.). Breeding vegetable crops. AVI, Westport, Conn.

Hoffman, P.G., M.C.Lego, and W.G. Galetto. 1983. Separation and quantification of red pepper major heat principles by reverse-phase high-pressure liquid chromatography. J. Agr. Food Chem. 31:1326-1330.

Kyle, M.M. and A. Palloix. 1997. Proposed revision of nomenclature for potyvirus resistance genes in Capsicum. Euphytica 88:231-239.

Villalon, B. 1981. Breeding peppers to resist virus diseases. Plant Dis. 65:557-562.

Villalon, B. 1983. TAM mild jalapeño pepper-1 pepper. HortScience 18:492-493.

Villalon, B., F.J. Dainello, and D.A. Bender. 1992. 'TAM Veracruz' hot jalapeño pepper. HortScience 27:184-185.

Villalon, B., F.J. Dainello, and D.A. Bender. 1994. 'Jaloro' hot yellow jalapeño pepper. HortScience 29:1092-1093.

Zitter, T.A. and A.A. Cook. 1973. Inheritance of tolerance to a pepper virus in Florida. Phytopathology 63:1211-1212. 